\title{
Munkamigráció a székelyföldi térségben Migráció és fejlődés, a migrációs döntések meghozatala
}

\author{
BODÓ JULIANNA ${ }^{1}$
}

\begin{abstract}
ABSZTRAKT
A munkavállalás céljából történő migráció napjaink egyik fontos társadalmi jelensége. Az alábbi tanulmány a székelyföldi munkamigráció rendszerváltás utáni helyzetébe nyújt betekintést. Vázolja azokat a legfontosabb trendeket, amelyek 1990-től napjainkig meghatározzák ezt a társadalmi folyamatot, és jelzi azokat a változásokat, amelyek mentén a munkamigráció egyes korszakai elkülöníthetők egymástól. A tanulmány kitér a migráció és a fejlődés kapcsolatának változó megítéléseire. Az utolsó alfejezet egy elemzésrészletet tartalmaz, amely a migráció következtében megmutatkozó új életvezetési tendenciák közegében vizsgálja a migrációs döntések meghozatalánakjelenségét.
\end{abstract}

KULCSSZAVAK: munkamigráció, Székelyföld, fejlödés, migrációs döntés

\section{ABSTRACT}

\section{Labor migration in Szeklerland. Migration and development, decision-making}

Migration for the purpose of employment is an important social phenomenon. The following study provides insight into the situation of labor migration in Szeklerland after the change of regime. It outlines the most important trends that define this social process from 1990 to the present and indicates the changes along which the different periods of labor migration can be separated. The study discusses the changing perceptions of the connection between migration and development. The last subchapter contains an analysis about the phenomenon of decisionmaking in the context of new lifestyle trends resulting from migration.

KEYWORDS: labor migration, Szeklerland, development, migration decision

${ }^{1}$ Társadalomkutató, KAM - Regionális és Antropológiai Kutatások Központja; egyetemi tanár, Sapientia EMTE, Csíkszeredai Kar. 


\section{TEMATIKUS TANULMÁNYOK - Székelyföld - térség és társadalom}

\section{Bevezetés}

A székelyföldi térségben a külföldre irányuló munkamigráció a rendszerváltás óta folyamatosan jelenlévő társadalmi jelenség. Az 1989 utáni külföldre utazás és munkavállalás lehetőségét a térség lakói nagyon hamar megragadták. Ennek több oka is van. Elsőként említhetjük, hogy a rendszerváltás előtti korszakra jellemző romániai megélhetési nehézségek (alapvető élelmiszerek, háztartási cikkek hiánya, a családi háztartások szükségleteinek kielégítési gondjai) olyan helyzetet alakítottak ki, amelyek a mindennapi életvezetést rendkívüli módon megnehezítették. A hirtelen megváltozott körülmények között - közvetlenül a rendszerváltás után lehetővé vált a külföldi utazás - a térség lakói a hiányok pótlásának legmegfelelőbb és leggyorsabb módját a külföldi munkavállalásban látták. Másodikként egy társadalomtörténeti tényszerűségre hivatkozom, amelynek megfelelően ebben a térségben az otthontól távoli, hosszabb-rövidebb ideig tartó munkavállalás egy olyan, a kultúra szövedékébe beépült praxisként működött/működik, amely az itt élők mindennapi gondjainak megoldására gyakrn alkalmazhatónak bizonyult. A térség lakói az adott korszak politikai-gazdasági helyzetének megfelelően választották meg a munkamigráció irányát, időtartamát, és határozták meg az elérendő célokat.

A térségre jellemző munkamigráció dinamikája, intenzitása igen korán felkeltette a kutatók érdeklődését. A rendszerváltás utáni korszakra fókuszálva a csíkszeredai KAM - Regionális és Antropológiai Kutatások Központja keretében 1995-1996ban végeztük el a témával kapcsolatos első kutatást (Bodó 1996). Ezt több olyan program követte, amely módszeresen foglalkozott a kérdéssel. Sor került ugyanakkor több olyan kutatásra is, amelynek fó célja nem a migráció volt, de érintette ezt a kérdést is. A 2000-es évek közepétől a Sapientia - EMTE társadalomtudományi tanszéken megalakult migrációkutató munkacsoport is bekapcsolódott ezekbe a kutatásokba. Vizsgálódásaink elsősorban a kulturális antropológia szemléletét és módszereit követik. Az évek során több száz interjú készült a térségből külföldre vándorló munkamigránsokkal. Ezek elemzése során arra törekedtünk, hogy az érintettek migrációs tapasztalatait belehelyezzük a térség társadalmi-kulturális kontextusába. Olyan képet igyekeztünk felvázolni a jelenségről, amely egyrészt napjaink térségi migrációjának legfontosabb jellemzőit mutatja meg, másrészt feltárja azokat a trendszerű változásokat, amelyek mentén a már több mint két és fél évtizedes folyamat korszakolása is kirajzolódik (Bodó 2008, Biró - Bodó 2009). A jelenség öszszefüggést mutat a nemzetközi migrációs trendekkel, ugyanakkor továbbra is magában hordozza a helyi kulturális mintáknak megfelelő jegyeket.

A következőkben csak röviden vázolom ezeket a trendszerű változásokat és az ezeknek megfelelő korszakokat. Az 1989 utáni időszakra jellemző, hogy a migráns távolságot tart a befogadó közegtől, a megkereshető pénzre koncentrál, az otthoni hiányok betöltése a kilépés kizárólagos célja. A kétezres évek elejétől már megfigyelhető egy olyan elmozdulás a munkamigránsok magatartásában, amely a transz- 


\section{TEMATIKUS TANULMÁNYOK - Székelyföld - térség és társadalom}

nacionalizálódás jeleit mutatja. Ez azt jelenti, hogy a külföldi munkavállaló már nem zárkózik el az idegen világtól, nem a pénzkeresetet tekinti kizárólagos motivációnak, hanem az idegen világ megismerését is fontosnak tekinti. A migráció ebben az esetben nem jelenti sem az idegen közegtől való teljes elhatárolódást, sem az otthontól való elszakadást, hanem az egyszerre, szimultán módon két helyhez kötődést támogatja. Ezt a váltást olyan tényezők teszik lehetővé, amelyek az utazási feltételek megkönnyítéséhez, az otthonnal történő kapcsolattartási formák leegyszerüsödéséhez és nem utolsósorban a külföldi munkavállalás hivatalossá válásához kapcsolhatók. A legutóbbi években pedig egy új, harmadik korszak kezdete látszik körvonalazódni. Ez a korszak továbbra is a transznacionális migráció jellegzetességeit hordozza, de ami a változást mutatja, az elsősorban olyan migráns-magatartásokban érhető tetten, amelyek a munkamigráció jelenségének automatizálódását mutatják. Ez azt jelenti, hogy a térség lakói akkor is a külföldi munkavállalás mellett döntenek, amikor az otthoni viszonyok valamelyest javulnak (munkahely, megélhetés), a kényszerek már nem egyértelműen és kizárólagosan az otthontól távoli munkavégzés irányába taszítják az egyént. Ebben a helyzetben a külföldi munka egyre hosszabb időre nyúlik, előre nem belátható, nincsenek olyan egyértelmű célkitűzések, amelyek a külföldi munkavégzés időtartamát meghatároznák. Előtérbe kerül a projektszemlélet, amely nem a hosszú távú tervezésre, hanem a gyors és előre nem mindig látható váltásokra alapoz (Bodó 2012, 2016a, 2016b).

\section{A migráció és a fejlődés kapcsolata a nemzetközi és romániai tapasztalatok függvényében}

Jelen tanulmányban a székelyföldi munkamigrációs kutatásoknak csak egy kis szelete - egy nagyobb elemzés részlete - kerül bemutatásra, amely a migráció és a fejlődés kapcsolatára fókuszál. Előtte egy rövid áttekintésben de Haas (2010), de Haan (2000) és Taylor (1999) munkái nyomán vázolom fel a migráció és fejlődés kapcsolatát vizsgáló munkákban megmutatkozó paradigmaváltás legfontosabb pontjait. A munkamigráció és a fejlődéselméleti megközelítések közti viszony áttekintése különösen alkalmas arra, hogy támogassa a munkamigrációs jelenségek természetes társadalmi folyamatként való kezelését.

Elsőként említem a neoklasszikus migrációelméletet, amely a migránsoknak kulcsszerepet tulajdonít a különböző térségek közti fejlődési különbségek kiegyenlítésében. Ez a migrációs elméletek optimista ágának nevezett szemlélet (Bertram 1986, Fraenkel 2006) a migrációt úgy tekintette, mint ami kiegyenlítődést eredményez a kibocsátó és a befogadó országok, térségek között. Úgy látták, hogy a kibocsátó közegben tapasztalható egyéni hasznosulások összeadódnak (például a hazaküldött pénzek), és makroszintű fejlődési folyamatokat indítanak el a kibocsátó közegben. 


\section{TEMATIKUS TANULMÁNYOK - Székelyföld - térség és társadalom}

Ez a megközelítés elsősorban gazdasági jellegű, és nem foglalkozik a munkamigráció társadalmi-kulturális aspektusaival.

A fenti, a migráció és fejlődés kapcsolatát taglaló optimista forgatókönyv később pesszimistábbra cserélődik (lásd: Taylor 1999), mert a vizsgálatok nyomán kiderült, hogy a folyamat csak átmeneti jelleggel sikeres, és egyre inkább a jelenség negatív hatásai mutatkoznak meg: erősödik a társadalmi dezintegráció, nő a függőség és az egyenlőtlenség, a kibocsátó közeg fokozódó elszegényedése is megmutatkozik, ugyanakkor a munkamigráció a kibocsátó közegből való végleges eltávozást is támogatja.

A munkamigráció árnyaltabb megközelítése később (Capello 2007, Jenkins 2000) a családot, a háztartást tekinti a munkamigráció meghatározó egységének, amely a megélhetés optikájából közelít a jelenséghez. Ezen elgondolás szerint a migrációs törekvéseket olyan alapvető emberi szükséglet mozgatja, amely a családok megélhetési lehetőségeinek javítási szándékából indul ki. Ehhez kapcsolódik a helyi fejlődés gondolata is (Sen 1999): egy adott térségben élők a térségre jellemző kulturális paradigmák mentén érzékelik azokat az életvezetési forgatókönyveket, amelyek közül választhatnak. Ilyenformán a munkamigráció által kiváltott hatások úgy jelenhetnek meg a migránsok egyéni törekvéseiben, hogy azok az egyéni és térségi/lokális fejlődés elemeivé válhatnak (de Haas 2010). Ebben a megközelítésben a makroszintű hatások szerepe kevésbé látszik fontosnak a család és az egyén szerepéhez viszonyítva.

A Romániára vonatkozó, a rendszerváltás utáni munkamigrációt vizsgáló kutatási anyagokban is kiemelt szerepet kap a migráció és a fejlődés kapcsolatának elemzése. Az Anghel, Botezat, Cosciug, Mana, Roman szerzőcsoport tanulmánya (2016) a romániai Nyugat-Európába irányuló munkamigrációt olyan folyamatként mutatja be, amely ebben a tekintetben a legdinamikusabb az európai térségben. A rendszerváltás utáni migráció gazdasági-társadalmi hatásait tekintve a hazautalt pénzösszegeknek az otthoni gazdasági következményeit vizsgálják, illetve azt, hogy a visszatérő migráció mennyiben segíti az otthoni vállalkozások elindítását, müködtetését.

Feraru (2011) a migráció és a fejlődés romániai, rendszerváltás utáni helyzetét vizsgálva szintén a hazautalások hatásaira helyezi a hangsúlyt, de felhívja a figyelmet arra is, hogy a már megjelenő mikroelemzések folytatására van szükség ahhoz, hogy a makrogazdasági mutatókon túllépve lehessen vizsgálni a jelenséget, mert a hazautalások hatását vizsgálva az derül ki, hogy ezek elsősorban mikroszinten, vagyis a családi gazdaságok és a lokalitások szintjén érvényesülnek leginkább.

Dumitru Sandu nevéhez több országos és regionális kutatás, illetve publikáció (Sandu 2000a, 2000b) kötődik, melyeknek fó témája a rendszeváltás utáni munkamigráció. Ha ezekből a munkákból a fejlődésre vonatkozó szegmensekre figyelünk, az derül ki, hogy a migránsok által termelt anyagi haszon elsősorban a családi gazdaságokban mutatkozik meg, illetve az egyéni/családi megélhetés javítására tett kísérletekben látszik leginkább. Legjellemzőbb esetek: a háztartás kurrens költségeinek 


\section{TEMATIKUS TANULMÁNYOK - Székelyföld - térség és társadalom}

fedezése, adósságok kifizetése, lakásépítés vagy annak felújítása, bővítése, tartós fogyasztási cikkek vásárlása, a jólét növelése, a gyerekek taníttatása.

Anghel (2009) esettanulmánya egy romániai városra koncentrálva azt mutatja be, hogy egy adott lokalitás keretei között a migráció sokkal inkább a lakosok, mint a település fejlődésben mutatkozik meg. Egy másik elemzés (Badescu - Stoian Tanase 2006) elsősorban a migráció kulturális hatásaival foglalkozik, mintegy társadalmi tőkeként értelmezve a migráció hasznosulását.

\section{A migráció és a fejlődés kapcsolata a székelyföldi kutatási tapasztalatok alapján}

A továbbikban a Székelyfölről külföldre irányuló, rendszerváltás utáni migrációs folyamatnak azon a kutatási tapasztalataiból vázolok néhény aspektust, amelyek ugyancsak a migráció és a fejlődés összefüggéseit vizsgálják. A 90-es évek elején a migráció hatása egyértelműen olyan anyagi hasznosulásként mutatkozott meg, amely az előző évtizedek hiányainak pótlását célozta. Később a transznacionális vonások folyományaként a migráció és a fejlődés kapcsolata is új megvilágítába került (Bodó 2016a). Ebben a korszakban a fejlődés továbbra is a családi háztartások keretében mutatkozik meg a legdominánsabban, kevés példát találunk arra, hogy a munkamigráció anyagi hozadéka a kibocsátó régió gazdasági fellendülését segítené elő. Van ugyan néhány példa sikeres vállalkozások elindítására is, de ennél sokkal magasabb azon esetek száma, ahol a háztartásokba fektetik be a megszerzett pénzt. Akárcsak a nemzetközi és a romániai kutatási tapasztalatok esetében, a székelyföldi kutatási eredmények is azt mutatják, hogy a hazaküldött/hazahozott pénz elsősorban a lakáskörülmények javítását, új gépkocsi vásárlását, tartós fogyasztási cikkek beszerzését eredményezi.

Fel kell figyelni ugyanakkor néhány olyan tényezőre, amely a közvetlen anyagi gyarapodásmellett olyan hasznosulási formákat mutat, amelyek közvetett formában fejlődési tényezőként léphetnek fel a kibocsátó közeg számára. Elsőként a tacit tudás, tacit befektetés jelenségét említem. A munkamigráció vonatkozásában gyakran felmerül az agyelszívás témája: azt a jelenséget nevezik meg ezzel a kifejezéssel, amelynek során a képzett munkaerő külföldre vándorlása következtében a kibocsátó közeg produktív, innovatív munkaerőt veszít. Ezzel szemben születtek meg az olyan kifejezések, mint az "agyak cirkulációja", illetve az "agy-gyarapodás" (De Haas 2010), amelyek azt jelzik, hogy a migránsok a külföldi munka során különböző típusú tudásra is szert tesznek, és hazatérve - amennyiben az otthoni környezet nyitott az új tudásra - anyagi tőkévé is konvertálhatják azokat. Itt a munka során szerzett tapasztalatok jelenthetnek befektethető tudástőkét, de az élettapasztalat, egy másik kultúra, életvitel, időbeosztás, munkakultúra terén szerzett ismeretek is fejlődési tényezővá válhatnak. 


\section{TEMATIKUS TANULMÁNYOK - Székelyföld - térség és társadalom}

A kibocsátó közeg fejlődését előmozdítható tényező lehet maga a tanulás is. Két esetben figyeltük meg a munkamigráció és a tanulás konkrét összekapcsolási lehetőségét: az egyik az, amikor a munkamigráció egyik motivációja a pénzkereset mellett explicit módon a tanulás, amelyet az otthoni környezetben fel lehet használni a munkaerőpiaci esélyek növelése céljából. A másik, tanulással összekapcsolódó jelenség: a gyermekek továbbtanulására, fiatalok esetében a saját tanulási költségeinek fedezésére fordított munkamigrációs jövedelem.

Meg kell még említeni a családok életminőségének javítására szolgáló hasznosulást is. Ez pénzben nem mérhető fejlődést jelent: nem egyértelműen anyagi gyarapodásról van szó, hanem az értékvilágban bekövetkezett, a külföldi muka hatásaként tételezhető változásokról. A családok mindennapi életében megfigyelhető elmozdulás a materiális értékek felől a posztmateriális értékek irányába azt jelzi, hogy a migránsok a külföldi munka alkalmával egy másik kultúrában tett megfigyelések birtokában olyan változásokat is beépítenek a családi életvitelbe, amely a rekreáció, a családtagok együtt töltött szabadideje, az egymás közti viszonyok megváltozása (a hagyományos paternalista viszonyokról a partneri kapcsolatformák felé) irányába mozdítja el az értékdimenziókat. A családi életvitelre gyakorolt hatás elsősorban a fiatal családok esetében figyelhető meg, és az elkövetkező, ide irányuló kutatások mutatják majd meg, hogy ezekben az életvezetési változásokban a családi jólét, illetve „jóllét” miként kapcsolód(hat) össze egymással.

Az alábbi fejezet egy olyan kutatás részét képezi, amely a székelyföldi munkamigráció vonatkozásában megmutatkozó változó életvezetési tendenciákat, ezen belül is az értékvilág és a fogyasztás új dimenzióit, a munkamigrációnak a tanuláshoz kapcsolódó mozzanatait, a migrációs döntések meghozatalában mutatkozó változó tendenciákat vizsgálta. Ezek a tematizációk a migráció és a fejlődés új megközelítési lehetőségein belül az életmódnak az anyagi vonatkozásain túli dimenzióira figyel$n^{2}{ }^{2}$. A kutatás - folytatásaként az előző években végzett migrációs témájú vizsgálatoknak - a székelyföldi munkamigráció transznacionális jegyeinek erősödését mutatta, ugyanakkor arra is rávilágított, hogy a migrációs magatartásokban egyre inkább előtérbe kerül az egyén szerepe. A vizsgálat során - a kulturális antropológia módszerét alkalmazva (interjúkészítés, esetleírás, megfigyelés) - azt tapasztaltuk, hogy habár a családi közeg továbbra is lényeges tényezőként jelenik meg, egyre meghatározóbb a migrációs hatásoknak az egyéni életvezetésbe történő beépülése. Ez a beépülés a migrációs folyamat olyan mozzanataiban érhető tetten, mint a tanulás, a fogyasztás, a döntési modellek, illetve az ezekhez kapcsolódó magatartások változásai.

Az elemzés négy szempontot követve négy alfejezetre tagolódik, ezek a következők: (1) a fogyasztás és befektetés, (2) a szabadidő eltöltési módja, (3) a tanulás

\footnotetext{
${ }^{2}$ A kutatás az MTA DOMUS program támogatásával zajlott.
} 


\section{TEMATIKUS TANULMÁNYOK - Székelyföld - térség és társadalom}

mint az emberi tőkébe való beruházás és (4) a munkamigrációs döntés meghozatala. A következőkben a negyedik témakör, a munkamigrációs döntéshozatal bemutatására kerül sor.

\section{A migrációs döntés meghozatala}

A migráció esetében a saját környezetből történő kilépést hosszabb-rövidebb ideig tartó mérlegelés, majd a döntés előzi meg. A döntés meghozatalának helye, aktorai, társadalmi környezete pedig fontos tényezői a migrációs folyamatnak. Nem mindegy ugyanis, hogy a külföldi munkát mérlegelő egyén meghozhatja-e önmaga a döntést, vagy valakinek az engedélyével, beleegyezésével, jóváhagyásával teheti csak meg azt. A döntés meghozatalában olyan szocio-kulturális tényezők játszanak szerepet, amelyek nemcsak a migráció jelenségére világítanak rá, hanem az adott családi, rokonsági, lokális környezet kontextusába is belehelyezik a migrációt. A táradalom mikro, mezo és makro szintje (állami, lokális, családi) különbözőképpen viszonyulnak az egyén migrációs szándékához, ez a viszonyulás pedig a tiltás és az egyéni szabad döntés két végpontja közt számtalan olyan helyzetet alakíthat ki, amely befolyásolja a migrációs attitűdöket.

A munkamigráció új gazdaságtana a 90-es évek első felében a migránsok viselkedését vizsgálva újból a családra, illetve a migránst kibocsátó háztartásra irányította a figyelmet (Massey et al. 1993, Stark 1991). Az egyén migrációs viselkedésének kontextusává a család, illetve a háztartás vált, ide irányult az az érdeklődés is, amely a migrációs döntések meghozatalát igyekezett kontextualizálni.

A székelyföldi munkamigráció esetében a döntések meghozatala annak megfelelően alakult, ahogyan az elmúlt két és fél évtized során maga a migráció jelensége is változott. A rendszerváltás után nagy dinamikával elindult külföldi munkavállalás jelenségét vizsgálva azt láttuk, hogy a migránsok a családi háztartások felhalmozódott hiányait igyekeztek pótolni a vendégmunkán szerzett pénzzel. A döntések is a családi közegben születtek meg, sőt, nem ritkán ennél szélesebb körben, rokoni vagy szomszédsági közegben. A '89 előttről még érvényes gyakorlat szerint ugyanis a kooperáció volt az egyik leghatékonyabb kezelési módja a hiánygazdaság következményeinek. Ennek megfelelően olyan nagyfokú családi, rokonsági és részben szomszédsági/baráti együttműködésre volt szükség, amely túllépett az egyes családok keretein, és a kölcsönös segítségnyújtások, viszonzások sűrű hálójába vonta az egyéni cselekvési lehetőségeket. Ennek folytatásaként a rendszerváltás utáni években az egyén időszakos kilépése a családi háztartásból olyan fennakadásokat okoz(hat)ott, amelynek kiküszöbölésére ugyanazokat a hálózatokat kellett múködtetni, amelyek a hiánygazdaság éveiben már kialakultak. A döntést tehát sokkal nagyobb szervezéssel és körültekintéssel, szélesebb kapcsolatháló bevonásával lehetett meghozni. A 2000-es évektől kezdve a helyzet megváltozott. A globalizációs tendenciák 


\section{TEMATIKUS TANULMÁNYOK - Székelyföld - térség és társadalom}

felerősödésével a migráció egyre inkább transznacionális jegyeket öltött magára. Mindez egy erős individualizációs folyamatot is eredményezett, ez pedig a migrációs döntések meghozatalában is változásokat hozott. A külföldi munkavállalás feletti döntést most már nem a szélesebb kapcsolatháló, de nem is föltétlenül a család hozza meg, hanem az egyén. A döntés meghozatala ugyanakkor mégsem teljesen csak az egyént érinti, hisz minden egyes migránsnak megvan az a családi beágyazódása, amely ha nem is veszi át teljesen a döntés jogát, de véleményezi és nyugtázza, avagy ellenzi azt. Akadályozó tényezőként ha nem is működik, de valamelyest befolyást mégis gyakorol(hat) az egyéni elhatározásra.

A döntések meghozatalának individualizálódásához még hozzájárul néhány tényező:

- A vendégmunka hasznosulása is részben kikerül a családi háztartások köréből. Nem ritkán az látszik, hogy a kereset felhasználása, befektetése, elköltése szintén egyéni meggondolások mentén történik, hisz maga a kitűzött cél is gyakran az egyén elképzeléseihez kapcsolódik.

- Továbbra is gyakori helyzet, hogy a külföldi munkavállalás az egész család anyagi jólétét, valamilyen közös cél elérését szolgálja. De még ezekben az esetekben is megfigyelhető, hogy maga a döntés, amely egy vagy két családtag külföldi munkavállalását határozza el, elsősorban az érintett migráns hatáskörében marad. Ezt a helyzetet a székelyföldi munkamigráció transznacionalizálódó jellege is előidézi: a kilépés már nem a "nagy ugrás", a nagy eltávozás paradigmáival írható le, hanem sokkal inkább egy „normális”, már megszokottá vált jelenségkén tételeződik, amely nem föltétlenül igényli az egész család körültekintő megfontolásait. A döntések meghozatalának esetében különbségek is megmutatkoznak: az individualizálódó döntéshozás különböző csoportok és helyzetek mentén eltéréseket mutat. Elsősorban az életkor és nemek mentén mutatkoznak meg ezek a különbségek.

\section{DÖNTÉS MEGHOZATALA AZ ÉLETKOR FÜGGVÉNYÉBEN}

Amikor a migrációs döntést az életkorral összefüggésben tárgyaljuk, óhatatlanul felmerülnek azok az életkorhoz kötődő preferenciák, amelyek a migránst a külföldi munkavállalás elhatározására juttatják. Nyilvánvalóan eltérnek a külföldi munka hasznosulásáról megalkotott elképzelések a különböző életkori kategóriák esetében, olyan tekintetben is, hogy azok mennyiben kötődnek a családi háztartáshoz, illetve mennyiben érintik csupán az egyént. 


\section{TEMATIKUS TANULMÁNYOK - Székelyföld - térség és társadalom}

\section{Fiatalok}

Mindenekelőtt azt kell megjegyezni a fiatal korosztállyal kapcsolatban, hogy jelenlétük a székelyföldi munkamigránsok körében az elmúlt évtizedben markánsan megnövekedett. A számbeli növekedéssel együtt az is fontos tényező, hogy szimbolikus súlyuk e területen szintén nagyobb lett. A munkamigráció „fiatalodása” nem azt jelenti, hogy valamilyen vezető pozícióra tettek szert a jelenség mentális elfogadtatása terén, inkább arra utal, hogy a székelyföldi munkamigráció egy plurális jelenséggé vált, ahol nincsen már olyan életkori kategória (mint volt a kilencvenes évek első felében: a középkorú férfiak), amely a jelenséget alapvetően meghatározná.

A fiatal migránsok értelemszerüen sokkal individualizáltabb szinten kezelik a kérdést. Céljaik sokkal inkább egyéni célok: kalandvágy, egy másik világ, egy másik kultúra megismerése, nyelvtanulás, saját céljaikra felhasználható fogyasztási javak beszerzése (gépkocsi, elektronikai felszerelések, saját lakás), taníttatási költségek kiegészítése, képzés, tanulás. A döntést befolyásoló tényezőkbe leginkább a kortárscsoport, barátok körében szerzett tapasztalatok játszanak bele. Családjuknak legtöbbször már csak akkor beszélnek elképzeléseikről, mikor a külföldi munkavállalás döntése megszületett bennük. Interjúalanyaink szinte mindannyian beszámolnak arról, hogy családjuk némi aggodalommal vette tudomásul elhatározásukat. Van, akit szülei nagyon féltenek, és nehezen fogadják el gyermekük döntését. Mások könnyebben meggyőzik családtagjaikat elképzeléseik helyességéről, különösen ott tapasztalható ez, ahol a családban már volt példa külföldi munkavállalásra. A családi előzmények a döntés meghozatalát és annak elfogadtatását is megkönnyítik.

„Valójában inkább támogattak, csak féltettek, hogy mi lesz, hogy egy idegen, egy teljesen idegen családhoz mentem ki, nem tudtam semmit, és nem hivataloson volt, úgyhogy, ha valami lesz. A mostani fejemmel az is lehet, hogy nem indulnék ki. Annyi mindent hallottam azóta, és akármilyen családhoz kerülhettem volna, úgyhogy nagyon szerencsém volt. Tényleg csak féltettek, amúgy támogattak, mert elmagyaráztam, és anyukámék is megértik, hogy tényleg most van lehetöségem, hogyha nekifogok dolgozni, akkor már vagy szabadságot kell kivenni, vagy ott kell hagyni, tehát már bonyodalmak, és jön a család is lassan, és megértették." (Nö, 24 éves)

Azok a fiatalok, akik már némileg függetlenné váltak, nem teljesen függnek szüleiktől (befejezték tanulmányaikat vagy már van itthoni munkaerőpiaci tapasztalatuk), sokkal inkább hoznak egyéni döntést, a család tulajdonképpen többnyire csak nyugtázza elhatározásukat. A még tanuló fiatalok (egyetemisták) esetében sem támasztanak akadályt a fiatal munkavállaló útjába, igaz, hogy esetükben legtöbbször csak rövidebb ideig tartó kilépésről van szó. Abban az esetben övezi nagyobb szülői aggodalom vagy lebeszélési kísérlet az elhatározást, amikor a még tanuló fiatal ta- 


\section{TEMATIKUS TANULMÁNYOK - Székelyföld - térség és társadalom}

nulmányai időleges felfüggesztését is tervezi egy hosszabb kilépés miatt. A tapasztalatok ugyanakkor azt mutatják, hogy ezekben az esetekben is sikerül végigvinni a munkavállalással kapcsolatos elképzeléseket.

\section{Középkorúak}

A középkorúak még mindig igen nagy számban képviseltetik magukat a székelyföldi munkamigráció közegében. Már nem játsszák azt a megatározó szerepet, amit másfél évtizeddel ezelőtt, de számuk ma is jelentős. A migráció hasznosulásaként esetükben sokkal inkább a családi hasznosulás érvényesül. Mindezt az a tény is magyarázza, hogy nagy többségükben már régen családot alapítottak, céljaik értelemszerűen elsősorban a család anyagi jólétének emelésére vagy fenntartására irányulnak. Megjegyzendő ugyanakkor, hogy még ezekben az esetekben is többségük a döntést - elmenjen-e külföldre dolgozni vagy sem - egyénileg hozza meg. A házastárssal való megbeszélés, egyeztetés természetesen nagyon fontos, de a velük készített beszélgetésekből az derül ki, hogy a döntés viszonylag könnyen talált elfogadtatásra családi körben. A célok kisebb mértékben egyéniek, mint a fiatalok esetében: a családi ház kibővítése, modernizálása, gépkocsivásárlás, gyerekek taníttatása, ritkább esetben utazás, pihenés, rekreáció. Ebben a körben gyakoribb a munkanélküliség vagy a csekély kereset taszító hatása, ugyanakkor meglepően sokan említették azt is, hogy csak így volt esélyük - pénzkeresettel egybekötve - világot látni.

„Szüleim mind a mai napig ellenzik, azt hogy kimenjek, dehát ha nincs munkalehetôség itthon, rávagyok utalva, hogy kint vállaljak munkát Lányaim azok már megszokták, hogy mennem kell, hiszen csak azért megyek, hogy tudjam őket segíteni." (Nő, 46 éves)

\section{Idősek}

Az idősek korosztálya sem hiányzik a migránsok köréből, természetesen kisebb létszámban vannak jelen. Kutatási tapasztalataink azt mutatják, hogy az ők esetükben még inkább jellemző, mint a középkorúaknál, hogy a külföldi munkamigráció melletti elhatározásukat egyénileg hozzák meg. Döntésüket csak akkor közlik családtagjaikkal, mikor az bennük már alaposan megérlelődött. A családtagok vegyes érzelmekkel viszonyulnak ehhez a döntéshez, de legtöbb esetben elfogadják azt. A célok itt is főleg a családhoz kötődnek, különösen akkor, ha a fiatalabbak szorulnak segítségre. Nem ritkák viszont azok az esetek sem, amikor a már nem fiatal, nyugdíjas személy függetlenül él családjától, és saját egyéni életkörülményeinek javítása okán dönt a külföldi munkavállalás mellett: saját külön lakás felújítása, modernizálása, felszereltségének javítása, vagy akár az egészség megőrzése, utazás, rekreáció. Olyan pél- 


\section{TEMATIKUS TANULMÁNYOK - Székelyföld - térség és társadalom}

dákat is tudunk, amikor nagyon erős motivációként szerepelt a világ megismerésének vágya. Idősebb beszélgetőpartnereink elmondása szerint fiatal családtagjaik inkább meglepődtek elhatározásukon, mintsem ellenezték azt. Megjegyzendő, hogy az időskorúakról vázolt kép elsősorban a nők tapasztalatai alapján körvonalazódott, mivel több idősebb női munkavállalóval találkoztunk, mint férfival.

„Hát elsőre ugye, szóba sem akarták hozni, hallani se akartak róla, de aztán ugye, mindig mesélem, hogy mennyire jól érzem magam, s azután pedig mellettem álltak, mikor mondtam, hogy megyek ki Magyarországra. Megértették, hogy nekem is jól jön a pénz, és így jobban tudom őket is segíteni. És hát a drága unokámnak mindent meg szeretnék adni. Jól fogadták a hírt, persze hiányoznak nekem is, meg én is nekik, de ha jobban lehet keresni, akkor ott jobban megéri. A rokonok is viszonylag jól fogadták, pedig gondoltam, hogy megmondják, hova megyek vén fejjel. De nem, sőt, támogatták a döntésemet." (Nő, 63 éves)

\section{A DÖNTÉS MEGHOZATALA A NEMEK FÜGGVÉNYÉBEN}

\section{Nők}

A nők esetében azt a fontos megfigyelést szükséges előrebocsátani, hogy a nők részvétele a munkamigráció területén erőteljesen megnövekedett. Trendszerűnek nevezhető ez a változás, és nem csak a Székelyföldön, hanem nemzetközi szinten is. A nők szerepét a migrációban egy ideig csak úgy tekintették, mint ami a férfiak elhatározásának függvényeként értelmezhető. Ilyenformán a női döntéshozatal sem került a kutatások előterébe, főleg ott nem, ahol a nőknek a férfi családtagoktól való függősége erőteljes volt. A vizsgált régióban (a Székelyföldön) némiképp módosítja a helyzetet az a tény, hogy itt a nőknek az otthonuktól távol történő munkavállalása már jó ideje kulturálisan elfogadott gyakorlatnak minősül (városi cselédkedés, majd később a szocializmus idején a gyári munka és az ezzel járó ingázás). Egyik előző, a nők külföldi munkavállalásával foglalkozó kutatásom már rávilágított arra (Bodó 2017), hogy jelen helyzetben a nők döntésüket egyedül hozzák meg, és családjukkal csak akkor közlik azt, amikor ők maguk már úgymond meggyőzték saját magukat elhatározásuk helyességéről, és erről családtagjaikat is képesek meggyőzni. Motivációik az életkor függvényében eltérnek egymástól: a fiatal lányok a fiatalokra általában jellemző módon fogalmazzák meg elképzeléseiket, az ők esetükben tulajdonképpen nincs különbség férfiak és nők között. A középkorú nők kilépési döntésüket hosszabb gondolkodás, latolgatás után hozzák meg, mint a férfiak. Körükből kerülnek ki azok, akik itthon vagy elveszítették állásukat, vagy nem keresnek eleget, vagy valamilyen magánéleti probléma (megözvegyültek, elváltak) készteti őket arra, hogy komoly lépésre - külföldi munkavállalásra - határozzák el magukat. Ezek a döntések 


\section{TEMATIKUS TANULMÁNYOK - Székelyföld - térség és társadalom}

nem is igazán azért nehezebbek, mert a családtagok kemény ellenállásába ütköznek - ezt viszonylag könnyen legyőzik -, hanem azért, mert kilépésüket a családi háztartás közegéből körültekintőbben kell megszervezniük. Amikor ezt az akadályt is sikeresen elhárítják (az otthoni munka, a családi életvezetés megszervezése), a döntés már nem okoz problémát.

„Édesanyám egyik felől támogatott, a férjem ellene volt, mivel még soha nem voltam külföldön, és ebben a korban minek akarok kimenni az ismeretlenbe, és féltett, hogy vajon mi fog történni... legelöször a mély vízbe... de aztán elbeszélgettünk, és beleegyezett abba ő is, hogy a kicsengetésekre meg az egyetemre nem lesz elég csak az ő fizetése, és jobb, ha megpróbálom én is. Aztán beleegyezett végül. Ök a rokonok, elsőre benne voltak, és mondták, hogy jól teszem, ha elmegyek, itthon úgysem keresek annyit, hogy kijöjjünk belőle, és pár hónap alatt sokkal többet keresek, mint itthon egy év alatt." (Nő, 44 éves)

\section{Férfiak}

A fiatal férfiak döntési helyzete nem különbözik a fiatal nőkétől. Beszámolóikból kiderült, hogy önállóan döntöttek, és családjuk nem gördített komoly akadályt elhatározásuk útjába. Céljaik inkább egyéni célok voltak, a fiatal korosztályra előbb már említett módon. A középkorúak esetében a kilépés célja sokkal kevésbé tekinthető individuálisnak, inkább a család életlehetőségeinek javítását tekintik szem előtt. Ők azok, akik leghatározottabban állították, hogy elhatározásukat a család is támogatta, és az esetleges kezdeti nézetkülönbségeket, ellenállást könnyű volt leszerelni. Sokan ezt azzal magyarázzák, hogy döntésük annyira logikus volt, annyira célravezető, sőt, egyedüliként célravezető, hogy nem is volt rajta latolgatnivaló, vitatkoznivaló. Kevesebben ugyan, de utaltak a férfi családfői szerepkörére, amely feljogosítja őket arra, hogy elvárják: döntéseiket a családtagoknak vita és ellenállás nélkül kell elfogadniuk.

„Végül is nagyon fiatal voltam, mikor először külföldre mentem munkát vállalni. Szüleim nem nagyon egyeztek bele, de én nagyon makacs gyerek voltam, így hát az utat a nyakamba vettem és elindultam a nagyvilágba. Itthon maradt az öcsém, és azért az sokat jelentett nekik. Anyukám sem és én sem bántam meg, hogy akkor kimentem szerencsét próbálni. Akkoriban igaz, nagyon nehéz volt, honvágyam volt, szinte minden héten haza akartam jönni, de hát nem lehetett, és örvendek, hogy a honvágyamat is legyőztem, és 6 évet kint tudtam maradni." (Férfi, 27 éves) 
TEMATIKUS TANULMÁNYOK - Székelyföld - térség és társadalom

Általában jellemző tehát a vizsgált népesség körében, hogy a döntések az egyén szintjén történnek. A fiatalok esetében a munkamigráció célja is az egyéni elképzelések mentén fogalmazódik meg. Ami pedig a középkorúakat, időseket illeti, a döntést szintén az egyén hozza meg, de a családi kontextusnak mint a vendégmunka célját sokkal inkább meghatározó tényezőnek, erősebb nyugtázó, elfogadó szerepe van.

\section{Összegzés}

Napjaink székelyföldi munkamigrációjának vizsgálata során az egyik felmerülő kérdés a migráció és a fejlődés kapcsolatára vonatkozik. A nemzetközi migráció transznacionális megközelítése és a mikroszinten végzett vizsgálatok előtérbe kerülése arra irányította a kutatói figyelmet, hogy a jelenséget érdemes egyrészt a kulturális antropológia holisztikus szemlélete által megközelíteni, másrészt a migráció fejlődésre gyakorolt hatásának vizsgálatát a háztartások szintjén is elvégezni. A szemléletváltásnak és a kutatási irányultságnak a módosulása lehetővé teszi, hogy a migráció hatását ne csupán a pozitív vagy negatív (hasznos vagy káros a kibocsátó közegre nézve) megítélések mentén vizsgáljuk, hanem nézzük meg azt is, hogy a kibocsátó közegben a háztartások és az egyének esetében milyen változó tendenciák érvényesülnek a munkamigráció következtében, és ezeknek a változásoknak a szocio-kulturális dimenziói milyen mértékűek és milyen további változásokat generálhatnak, valamint hogy ezek hordozzák-e a fejlődés tényezőit is.

A rendszerváltás utáni székelyföldi munkamigrációt vizsgáló kutatási tapasztalataink azt mutatják, hogy az azóta eltelt majdnem három évtizedes időszakban a jelenség sokat változott. A kiinduló helyzethez képest (erős határmegvonás a kibocsátó és a befogadó közeg között) a migráció transznacionalizálódása ebben a térségben is megfigyelhető, ami a két szféra - kibocsátó és befogadó közeg - közeledését, a migránsoknak a két világhoz való szimultán kötődését mutatja. A kulturális antropológiai szemléletmód és kutatási módszer felhasználásával elvégzett kutatásaink a migráció és a fejlődés kapcsolatát tekintve azt mutatják, hogy az elmúlt évtizedekben elsősorban a családi életvezetés terén mutatkoztak meg leginkább a változások.

Ha a családot tekintjük a migráció alapvető egységének, akkor a családi és egyéni életlehetőségek javítási szándékával találkozunk a migrációs döntések meghozatalát tekintve. Az itt bemutatott elemzésrészlet is ezt a tendenciát igazolja. A migrációs döntéseket vizsgálva azt látjuk, hogy ezek a családok szintjén mennek végbe, ugyanakkor erősödik az egyének szerepe a döntés meghozatalában. Minderre azért fontos figyelmet fordítani, mert a döntési mechanizmusok változása azokra a szocio-kulturális tényezőkre is rávilágít, amelyek módosulásai mentén a vizsgált közösség más aspektusai is élesebb megvilágításba helyeződnek. A migrációs döntések meghozatalának helyzetei - életkori (fiatalok, középkorúak, idősek) és nemi (férfi, nő) ka- 


\section{TEMATIKUS TANULMÁNYOK - Székelyföld - térség és társadalom}

tegóriák vonatkozásában vizsgálva azokat - azt mutatják, hogy a migráció hatásai elsősorban a család és az egyén szintén jelentkeznek, modernizációs tendenciákat is jelezve, amelyek az individualizáció térnyerésére, a fogyasztói magatartás megerősödésére, az értékvilág esetében pedig a posztmateriális értékek előretörésének irányába mutatnak.

\section{Irodalom}

Anghel, R. G. - Botezat, A. - Coșciug, A. - Manafi, I. - Roman, M. (2016): International Migration, Return Migration, and their Effects: A Comprehensive Review on the Romanian Case. IZA DP No. 10445, December.

Anghel, R. G. (2009): Schimbare social sau dezvoltare? Studiu de caz într-un oraş din România: Efectele cuturale ale migraţiei forței de muncă. In: Anghel, R. G. - Horváth I. (szerk.): Sociologia migraţiei. Polirom, Iaşi.

Bădescu, G. - Stoian, O. - Tănase, A. (2006): Efectele cuturale ale migraţiei forței de muncă. In: Anghel, R. G. - Horváth I. (szerk.): Sociologia migrației. Polirom, Iaşi.

Bertram, I. G. (1986): Sustainable Development in Pacific Micro-Economies. World Development 14(7): 809-992.

Bodó J. (szerk.) (1996): Elvándorlók? Vendégmunka és életforma a Székelyföldön. Csíkszereda, Pro-Print Könyvkiadó.

Bodó J. (2008): Diskurzusok és életutak a migráció tükrében. Scientia Humana, Budapest.

Bodó J. - Biró A. Z. (2009): Értékek a transznacionális térben. Székelyföldi munkamigránsok értékorientációi. Antropológiai Múhely (15) 2009: 7-36.

Bodó J. (2009): Transznacionális migráció - kutatási lehetőségek. In: Bodó J. - Kiss A. (szerk.): Kultúra - kommunikáció - innováció. Státus, Csíkszereda. 32-40.

Bodó J. (2012): Változó életvezetési tendenciák a székelyföldi munkamigráció közegében. Az értékvilág és a fogyasztás új dimenziói. Kézirat.

Bodó J. (2016 a): Határátlépések, térbeélések. Iskolakultúra, 2016. január, 20-30.

Bodó J. (2016 b): Migráció és fejlődés napjaink székelyföldi társadalmában. In: Biró A. Z. - Bodó J. (szerk.): Helyzetek és változások. Székelyföldi társadalomtudományi kutatások a DOMUS program támogatásával. Csíkszereda, Státus Kiadó. 36-54.

Bodó J. (2017): A nők szerepe a székelyföldi munkamigráció társadalmi folyamatában. Antro-pólus, 2. évf. 1. sz. 2017, 101-114.

Capello, R. (2007): A forecasting territorial model of regional growth: the MASST model. The Annals of Regional Science, 4, 753-787. 


\section{TEMATIKUS TANULMÁNYOK - Székelyföld - térség és társadalom}

De Haan, A. - Brock, K. - Carswell, G. - Coulibaly, N. - Seba, H. - Ali Toufique, K. (2000): Migration and Livelihoods: Case Studies in Bangladesh, Ethiopia and Mali. IDS Research Report 46. Institute of Development Studies, Brighton, Sussex.

De Haas, H. (2010): Migration and development: a theoretical perspective. International Migration Review. Vol. 44. No. 1, 1-38.

Feraru, D. P. (2011): Migraţie si dezvoltare. Aspecte socio-economice şi tendințe. Iasi, Editura Lumen.

Fraenkel, J. (2006): Beyond MIRAB. Do Aid and Remittances Crowd Out Export Growth in Pacific Microeconomies? Asia Pacific Viewpoint 47(1): 15-30.

Massey, D. S. - Arango, J. - Hugo, G. - Kouaouci, A. - Pellegrino, A. - Taylor, J. E. (1993): Theories of International Migration: A Review and Appraisal. In: Poulation and Development Review 19(3): 431-466.

Jenkins, T. N. (2000): Putting postmodernity into practice: endogenous development and the role of the traditional cultures in the rural development of marginal regions. Ecological Economics, 34(3): 301-304.

Sandu, D. (2000a): Migraţia transnaţională a romanilor din perspectiva unui recensământ comunitar, Sociologie Romaneasca 3-4, 5-50.

Sandu, D. (2000b): Lumile sociale ale migraţiei româneşti în străinătate. Iaşi, Polirom.

Sen, A. (1999): Development as Freedom: A Global Perspective. Longman, Essex.

Stark, O. (1991): The Migration of Labor. Blackwell, Cambridge \& Oxford.

Şerban, M. (2011): Dinamica migraţiei internaţionale: un exerciţiu asupra migraţiei românești în Spania (International migration dynamics: an exercise on Romanian migration to Spain) Iaşi, Lumen.

Taylor, E. J. (1999): The New Economics of Labour Migration and the Role of Remittances in the Migration Process. International Migration 37(1): 63-88. 